\title{
Katı Atıklar için Optimum Güzergâh Tespiti ve Alansal Dağılım Haritalarının CBS Ortamında Oluşturulması: Suruç (Şanlıurfa) Örneği
}

\author{
Mehmet Emin ÇAKIR ${ }^{1}$, Ayşegül DEMIR YETIŞS²*, Mehmet İrfan YEŞİLNACAR ${ }^{1}$, \\ Mustafa ULUKAVAK ${ }^{3}$
}

${ }^{1}$ Harran Üniversitesi, Çevre Mühendisliği Bölümü, Şanlıurfa

${ }^{2}$ Bitlis Eren Üniversitesi, Çevre Mühendisliği Bölümü, Bitlis

${ }^{3}$ Harran Üniversitesi, Harita Mühendisliği Bölümü, Şanlıurfa

(ORCID: 0000-0002-7219-0558)(ORCID: 0000-0003-4745-2445)

(ORCID: 0000-0001-9724-8683) (ORCID: 0000-0003-2092-3075)

\begin{abstract}
Öz
Yerel yönetimler için, katı atıkların toplanması ve taşıma işlemleri, maliyet bakımından en yüksek paya sahiptir. $\mathrm{Bu}$ nedenle, bu süreçlerin iyi yönetilmesi, maliyet, çevre ve zaman açısından büyük önem teşkil eder. Aksi durumlarda; aşırı yakıt tüketimi, zaman israfi, amortisman gideri, çevre ve kamu sağlığı açısından önemli problemler ortaya çıkar. Bu bağlamda çalışma; bahsedilen hususların, Suruç Belediyesi (Şanlıurfa) özelinde irdelenmesini içermektedir. Çalışmada katı atıkları toplama sistemine ait yol ağları, çalışma alanının demografik yapısı ve bu bölgede ortaya çıkan atık miktarları ile ilgili veri setleri oluşturulmuştur. Bu veriler yardımıyla, katı atık toplama ve taşıma operasyonlarında, CBS tabanlı rota ve güzergâh optimizasyonu ile her mahalleye ait optimum güzergâh tespiti yapılmış; alansal katı atık dağılım haritaları çıkarılmış ve fayda-maliyet ilişkisi değerlendirilmiştir.
\end{abstract}

Anahtar kelimeler: Katı atık, CBS, optimum güzergâh, alansal dă̆ılım haritası, Suruç (Şanlıurfa).

\section{Determination of the Optimum Routes and Performing of the Spatial Distribution Maps for Solid Waste Using GIS: A case of study from Suruç (Şanlıurfa)}

\begin{abstract}
For local administrations, the collection and transport of solid wastes has the highest share in cost. Therefore, good management of these processes is of great importance in terms of cost, environment and time. Otherwise, significant problems arise in terms of excessive fuel consumption, waste of time, depreciation expense, environment and public health. In this context, this study includes the examination of the issues mentioned in the municipality of Suruç (Şanlıurfa). At the end of the study, data sets related to road network about collection system, demographic structure and solid waste amounts were formed. With the help of these data, GIS-based route and route optimization was performed to determine the optimum route for each neighborhood in solid waste collection and transportation operations. spatial solid waste distribution maps were extracted and the cost-benefit relationship was evaluated.
\end{abstract}

Keywords: Solid waste, GIS, optimum route, spatial distribution map, Suruc (Sanliurfa).

\section{Giriş}

Modernleşmenin ve buna bağlı olarak ihtiyaçların giderek artmasıyla birlikte, günlük oluşan insan kaynaklı atık miktarında önemli bir artış meydana gelmiştir [1]. Gerek evsel, gerekse endüstriyel

"Sorumlu yazar: ademir@beu.edu.tr

Geliş Tarihi: 14.11.2018, Kabul Tarihi: 29.03.2019 
nitelikli kaynakların tüketiminin hızlı bir şekilde artmasına paralel olarak gerçekleşen bu artış, günümüzde insan sağlığını önemli ölçüde tehdit etmektedir [2].

Katı Atık Yönetimi'nin ilk aşaması katı atık üretimidir. Her geçen gün gerçekleşen katı atık miktarındaki artış, nitelik olarak çeşitlilik gösteren katı atık üretimi, günümüz katı atık yönetiminde birçok araştırıcı ve uygulayıcının "azaltma" ilkesi üzerine yoğunlaştığı bir aşamadır. Herkesin birleştiği nokta ise bir taraftan atık toplama ve bertarafına yönelik en ileri teknolojiler geliştirilirken, diğer taraftan da çıkan atığın azaltılmasının bir gereklilik olduğu şeklindedir. Bu halkın eğitimiyle ve ayrıca üreticinin bilinçlendirilmesi ve yönlendirilmesiyle gerçekleşebilecek bir olgudur [3].

Katı atık toplama ve taşımada araçların, atık toplamak için bir noktadan başlayıp yine aynı noktaya döndüğü güzergâha tur denilmektedir. Bu tur belirleme, katı atık yönetim sistemi harcamaların en maliyetli kısmını oluşturduğundan daha sistematik çözümler ve bilimsel yöntemler araştırılmalıdır. Atıkların verimli ve ekonomik olarak toplanması için belediyelerin en kısa süre içerisinde, maksimum miktarda atık toplanmasını sağlayacak planları yapmaları gerekmektedir. Atıkların toplanacağı yollar için güzergâh çalışmaları sahada yapılmalıdır [4, 5]. Bunun yanında atıkların toplanması ve taşınmasından da belediyeler sorumludur. Atık Yönetimi Yönetmeliği'ne göre belediyeler "yönetiminden sorumlu olduğu atıkların taşımasında kullandıkları araçların kaydını tutmakla, araç takip sistemi kurmakla ve talep edilmesi halinde kayıtları bakanlığa ve il müdürlügüne sunmakla" yükümlüdürler [6].

Mevcut evsel atık toplama araçlarının turları incelenerek en düşük maliyet ile en yüksek dolulukta atığı en kısa süre ve mesafede toplama ve taşıma turları bakımından optimizasyon yapılmalıdır. Günümüzde birçok belediye ve atık toplama şirketleri bu çalışmaları göz ardı ederek tamamen sezgisel davranışlarla atık toplama işlemlerini gerçekleștirmektedir. Bu da bilimsellikten ve mühendislikten uzak iyi bir planlama yapılmadan katı atık toplama ve taşıma güzergâhı açısından tamamen işçilerin inisiyatifinde ilerleyen bir rota yaklaşımı dikkate alındığını göstermektedir.

Bu çalışmada; Şanlıurfa'nın Suruç Belediyesi hizmet sahası içerisinde faaliyet gösterilen katı atık toplama sisteminin yol ağları, demografik yapı ve atık miktarları ile ilgili veri bankası oluşturulması, elde edilecek veriler 1şığında katı atık toplama ve taşıma operasyonları için güzergâh optimizasyonunun yapılması ayrıca maliyet minimizasyonu sayesinde de etkinliğin arttırılması ve ekonomikliğin sağlaması amaçlanmıştır.

\section{Materyal ve Metot}

Suruç ilçesi Doğu Anadolu Bölgesi’nde Şanlıurfa İlinin güneybatısında yer almaktadır (Şekil 1). Suruç ilçesi 10 merkez mahalle, 85 kırsal mahalle ve 126 mezrası bulunan bir ilçedir. Çalışma alanı olarak; Aligör Mahallesi, Aydın Mahallesi, Barış Mahallesi, Sarayaltı Mahallesi, Yıldırım Mahallesi, Hürriyet Mahallesi, Dikili Mahallesi, Cumhuriyet Mahallesi, Demokrasi Mahallesi ve Yenişehir Mahallesi olmak üzere ilçenin 10 merkez mahallesi seçilmiştir. İlçedeki merkez mahallelerin katı atıkları her gün düzenli bir şekilde Suruç Belediyesi tarafından toplanırken kırsal mahallelerin katı atıkları ise yine belediyeye ait olan 7 adet arkadan yüklemeli, hidrolik sıkıştırmalı araçlarla toplanmaktadır. Uygulamanın gerçekleştirildiği bu bölgede katı atıkların toplanması, hareketli konteyner sistemi kullanılarak yapılmaktadir.

Suruç ilçesinde katı atık yönetimi için Coğrafi Bilgi Sistemleri (CBS) kullanılmıştır. Çok farklı uygulama alanlarına sahip Coğrafi Bilgi Sistemleri "karmaşı planlama ve yönetim sorunlarının çözülebilmesi için tasarlanan ve mekândaki konumu belirlenmiş verilerin toplanması, yönetilmesi, işlenmesi, analiz edilmesi ve karar verme süreci için modellenmesi ve görüntülenebilmesini sağlayan donanım, yazılım ve yöntemler sistemi" olarak ifade edilebilir [7, 8].

Suruç İlçesi merkez mahalleleri için güzergâh belirleme ve alansal çöp (katı atık) dağılım haritalarının oluşturulmasında ArcGIS 10.5 yazılımı kullanılmıştır. Konteynerlere ait konum bilgilerinin tespiti için Magellan Explorist 500 el tipi GPS cihazı kullanılmıştır. Altlık haritaların oluşturulmasında, yol verilerinin doğruluğunun kontrol edilmesi ve GPS cihazına ait verilerinden kaynaklanan konumlama hatalarının düzeltilmesi için Google Earth Pro yazılımı kullanılmış, konteynerlere ait konum bilgileri de bu bağlamda altlık haritayla ilişkilendirilmiştir. Haritaların hazırlanmasında kullanılan; yol, sokak, cadde ve mahalle sınırlarının elde edilmesi ve yol verilerinin, CBS sisteminin kullanabileceği formata dönüştürülebilmesi için Global Mapper 17 yazılımı kullanılmıştır. Çalışmada Dijkstra Algoritması en 
düşük maliyetli yolun bulunması ve en kısa yol problemlerinin çözümü için en etkin algoritmalardan biri olup, ağırlıklandırılmış bir çizgide (ağda) iki dügüm noktası arasındaki en kısa yolu bulmayı amaçlamaktadır. Kenarlara verilen ağırlıklar uzaklık, maliyet ve zaman gibi kriterlerin belirlenebilmesi için de kullanılabilir. Dijkstra algoritması bir çizgide belirlenen bir kaynaktan aynı zamanda tüm diğer hedef noktalara en kısa yolları bulabildiği için tek kaynaklı en kısa yol algoritması olarak da bilinir. Alansal katı atık dağılım haritalarının hazırlanmasında da ArcMap yazılımının eşyükselti eğrileri prensibi ile çalışan IDW aracı kullanılmıştır. IDW aracı bilinen değerler yardımıyla bilinmeyen noktalara ait değerlerin belirlenmesi için kullanılan bir enterpolasyon tekniğidir. Enterpole edilecek noktaları araştırırken mesafeye bağlı ağırlıklar kullanır ve yakındaki noktaların uzaktaki noktalardan daha fazla aktarlığa sahip olması esasına dayanır. Bu teknik noktadan uzaklaştıkça ağırlığı azalan ve değerlerin ağırlıklı ortalamasına göre bir yüzey enterpolasyonu gerçekleştirir $[9,10,11]$. Haritalardaki katı atık miktarının $\mathrm{m}^{3}$ birimindeki renklendirmeleri, $\mathrm{Z}$ parametresine göre oluşturulurken, bölgedeki konteynerlerin konum bilgilerine ait $\mathrm{X}$ ve $\mathrm{Y}$ parametrelerinin bir fonksiyonu olarak IDW araci kullanılmıştır.

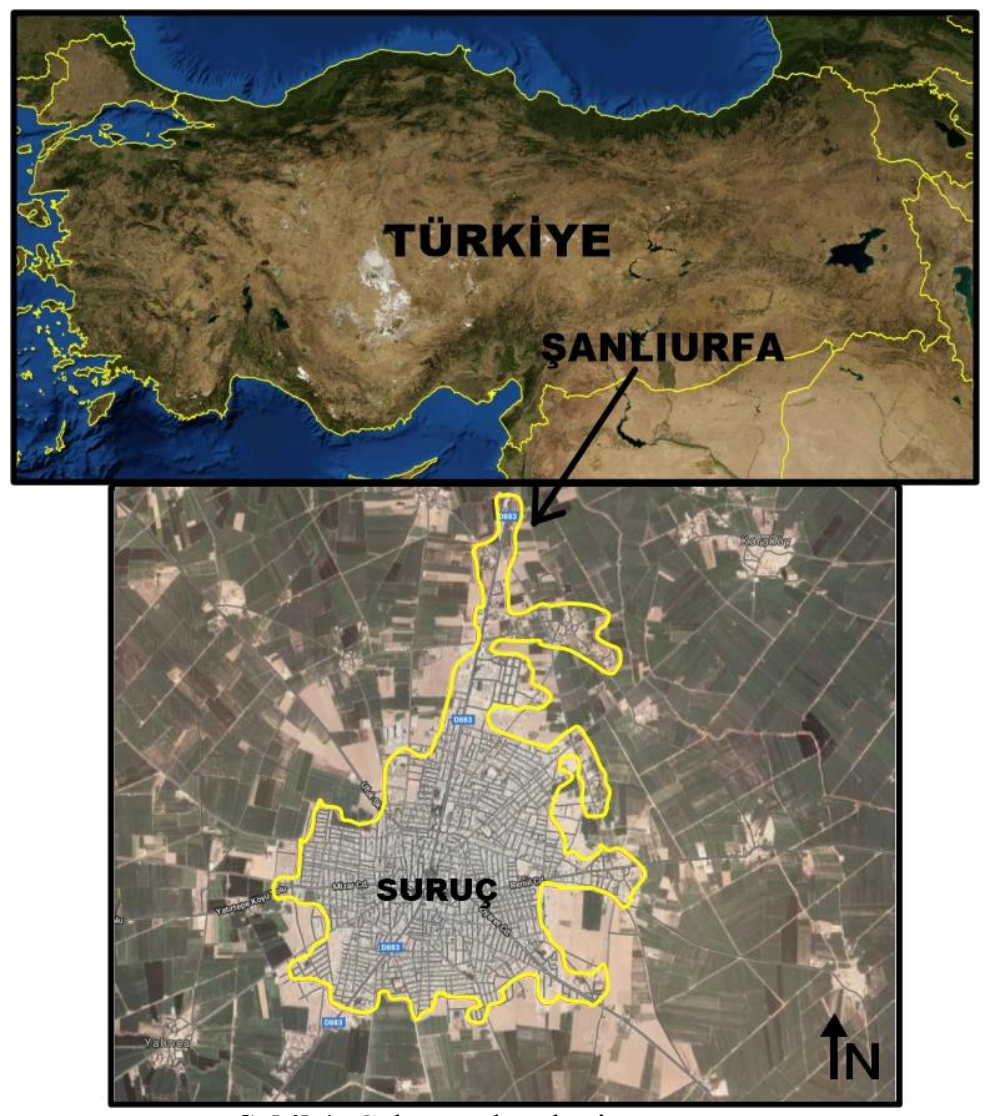

Şekil 1. Çalışma alanı haritası

\section{Bulgular ve Tartışma}

Bu çalışmada; CBS kullanılarak katı atık toplama, optimum güzergah (taşıma optimizasyonu) ve alansal katı atık dağılım haritaları hazırlanmıştır. Bu çerçevede güzergâh analiz optimizasyonu ve alansal katı atık dağılım haritaları için gerekli veriler belirlenmiştir. Her bir verinin hangi şekilde kullanılması gerektiği ve hangi analiz yönteminin seçilmesi gerektiği tespit edilmiştir. Buna göre Şanlıurfa ili Suruç ilçesinin katı atık toplama ve optimum güzergah tespitinin yapılabilmesi için ArcMap yazılımının network analiz modülü kullanılmıştır. En küçük kapsayan ağaç metoduyla aynı mantıkta çalışan bu yazılım, elde edilmiş katı atık koordinatlarını yol verisi üzerinde, aralarındaki en kısa mesafeleri hesap ederek numaralandırıp, bu numaralar arasındaki optimum güzergâhı bizlere vermektedir. Güzergâh belirleme işlemi 10 merkez mahalle için ArcMap yazılımı Network Analiz modülü kullanılarak güzergâh belirleme aracı ile optimum güzergâhlar ortaya çıkarılmıştır. Güzergâhların durak noktalarını 
çöp konteynerleri oluşturmaktadır. 10 merkez mahallenin toplam güzergâh uzunluğu 112.56 km, durak (çöp konteyner) sayısı 853 adet olarak tespit edilmiştir. Tablo 1'de Suruç ilçesi merkez mahallelerinin durak sayısı verileri ve optimum güzergâh uzunluk verileri ile atık miktarları verilmiştir. Her bir mahalle için başlangıç noktası araç çıkış alanı olan belediye garajını temsil ederken, bitiş noktası ise katı atık transfer istasyonunu ifade etmektedir.

Tablo 1. Suruç ilçesi merkez mahalleleri durak, güzergâh verileri ile atık miktarları

\begin{tabular}{ccccc}
\hline No & $\begin{array}{c}\text { Mahalle } \\
\text { Adları }\end{array}$ & $\begin{array}{c}\text { Güzergâh } \\
\text { Uzunlukları } \\
(\mathbf{k m})\end{array}$ & $\begin{array}{c}\text { Durak Sayısı } \\
(\mathbf{a d e t})\end{array}$ & $\begin{array}{c}\text { Atık Miktarı } \\
\left(\mathbf{m}^{\mathbf{3}}\right)\end{array}$ \\
\hline 1 & Aligör & 20.58 & 148 & $0.4-0.8$ \\
2 & Aydın & 10.99 & 101 & $0.4-1.2$ \\
3 & Barış & 6.50 & 46 & $0.4-0.8$ \\
4 & Cumhuriyet & 13.22 & 128 & $0,4-1,2$ \\
5 & Demokrasi & 8.72 & 71 & $0.4-2.0$ \\
6 & Dikili & 8.59 & 45 & $0.4-0.8$ \\
7 & Hürriyet & 9.47 & 43 & $0.4-0.8$ \\
8 & Sarayaltı & 12.58 & 103 & $0.4-0.8$ \\
9 & Yenişehir & 7.56 & 58 & 0.4 .1 .2 \\
10 & Yldırım & 14.35 & 110 & $0.4-0.8$ \\
\hline
\end{tabular}

Kişi başına düşen günlük atık miktarı 1.17 kg olarak 2017 yılı TÜİK verilerinden alınmıştır [12]. Bu veriler ışığında 64422 nüfuslu Şanlıurfa ili Suruç ilçesi merkez mahallelerinin yıllık atık miktarı 27 135 ton olarak hesaplanmıştır.

Bir alanın katı atık dağılım haritasını çıkarmak için ihtiyaç duyulan en önemli faktör alandaki katı atık miktarlarının tespitidir. Çöp konteynerleri ihtiyaca göre bölgelere yerleştirilmiş olup o alandaki kirliliğin durumu hakkında bilgi veren bir göstergedir. Buna göre oluşturulan alansal katı atık dağılım haritaları mahallelerdeki bölgelerin kirlilik alanlarını ve bu alanlar içerisinde hangi kısımlarda kirliliğin yoğun olduğunu göstermektedir. Diğer bir ifadeyle mahalle sınırlarında katı atığın daha çok oluştuğu yerler hakkında bizlere bilgi vermektedir. Bu da herhangi bir çalışma veya hesaplama işlemi yapmaya gerek duyulmaksızın bölgede gerçekleştirilecek temizlik, atık toplama ve taşıma işlemleri için ciddi kolaylık sağlama noktasında önemli bir alternatif sunmaktadır. Mahallelerin X ve Y koordinatlarına bağlı $\mathrm{Z}$ ifadeli katı atık miktarı verileri baz alınarak her bir mahalle için hazırlanan alansal katı atık dağılım haritaları Şekil 2-11'de verilmiştir.

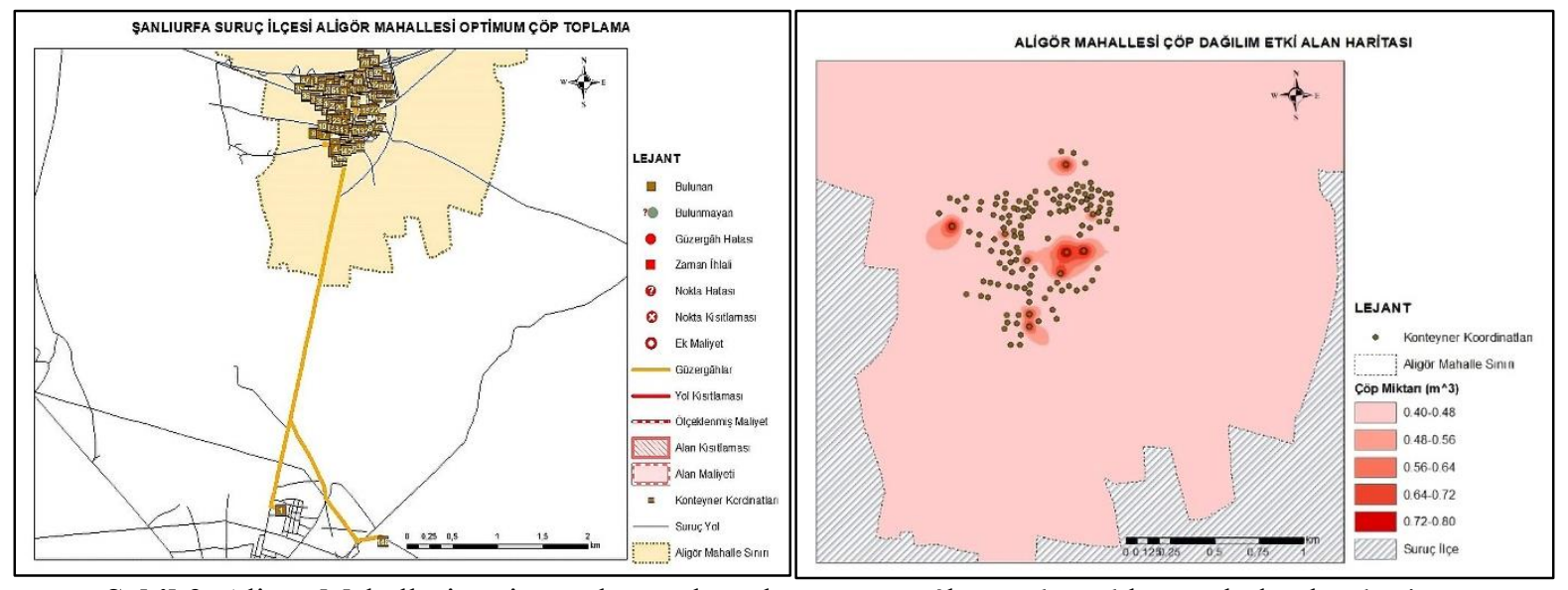

Şekil 2. Aligör Mahallesi optimum katı atık toplama güzergâhı ve alansal katı atık dağılım haritası 

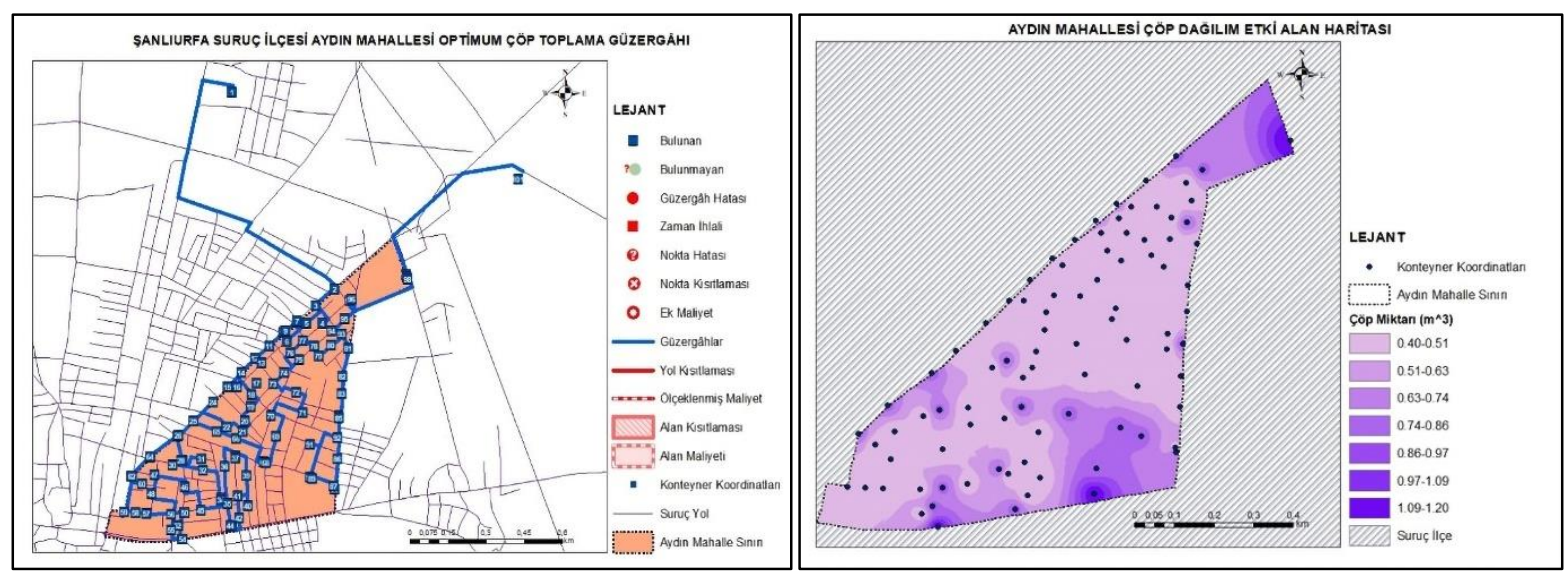

Şekil 3. Aydın Mahallesi optimum katı atık toplama güzergâhı ve alansal katı atık dağılım haritası

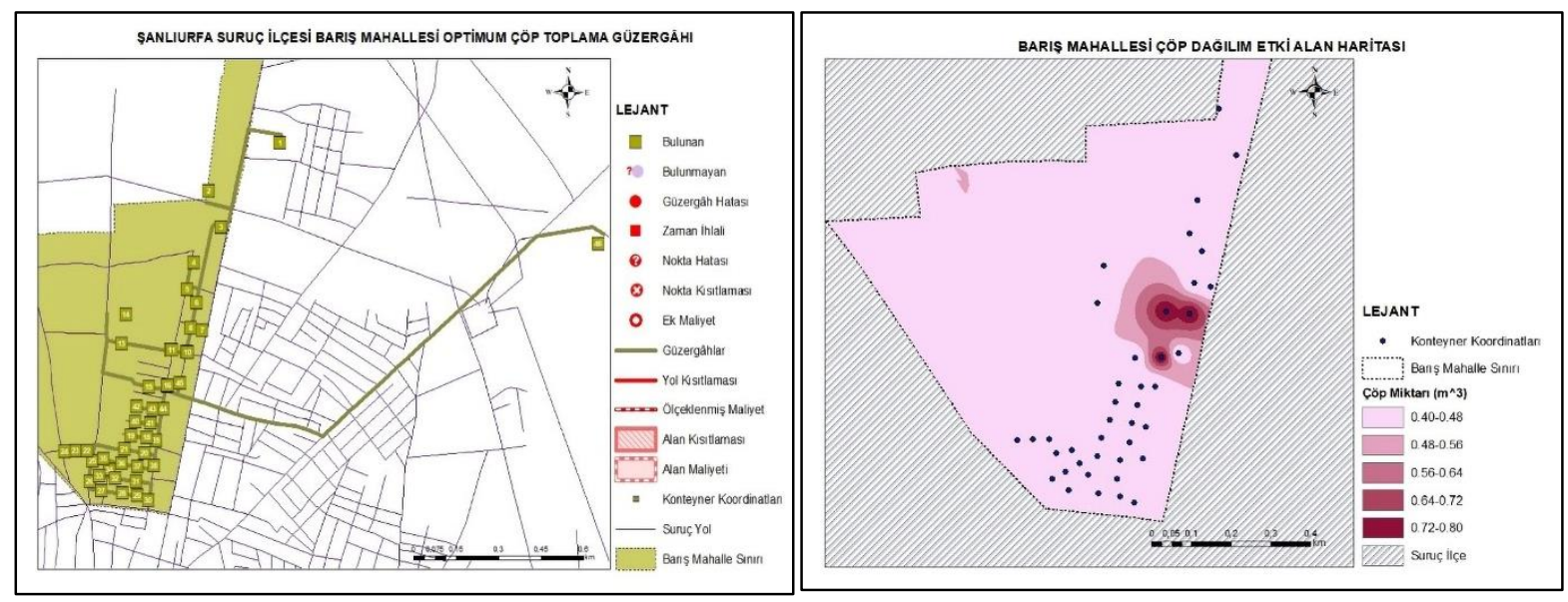

Şekil 4. Barış Mahallesi optimum katı atık toplama güzergâhı ve alansal katı atık dağılım haritası
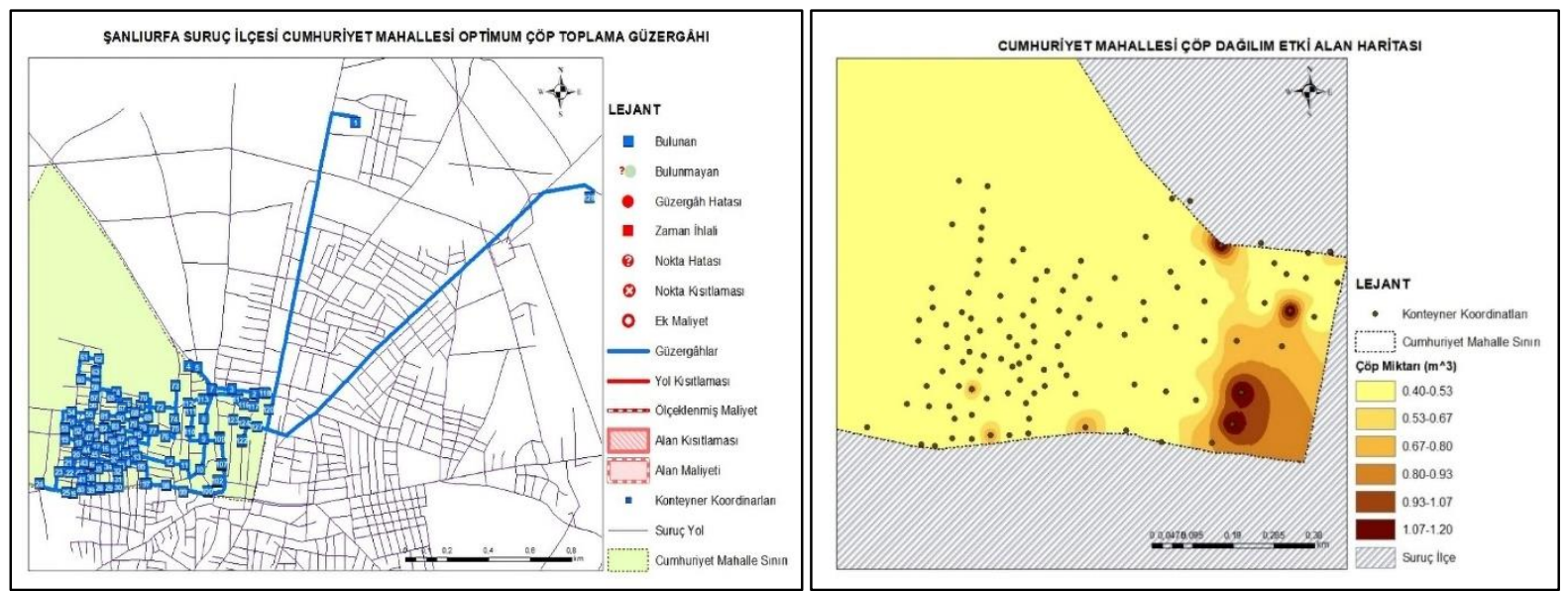

Şekil 5. Cumhuriyet Mahallesi optimum katı atık toplama güzergâhı ve alansal katı atık dağılım haritası 


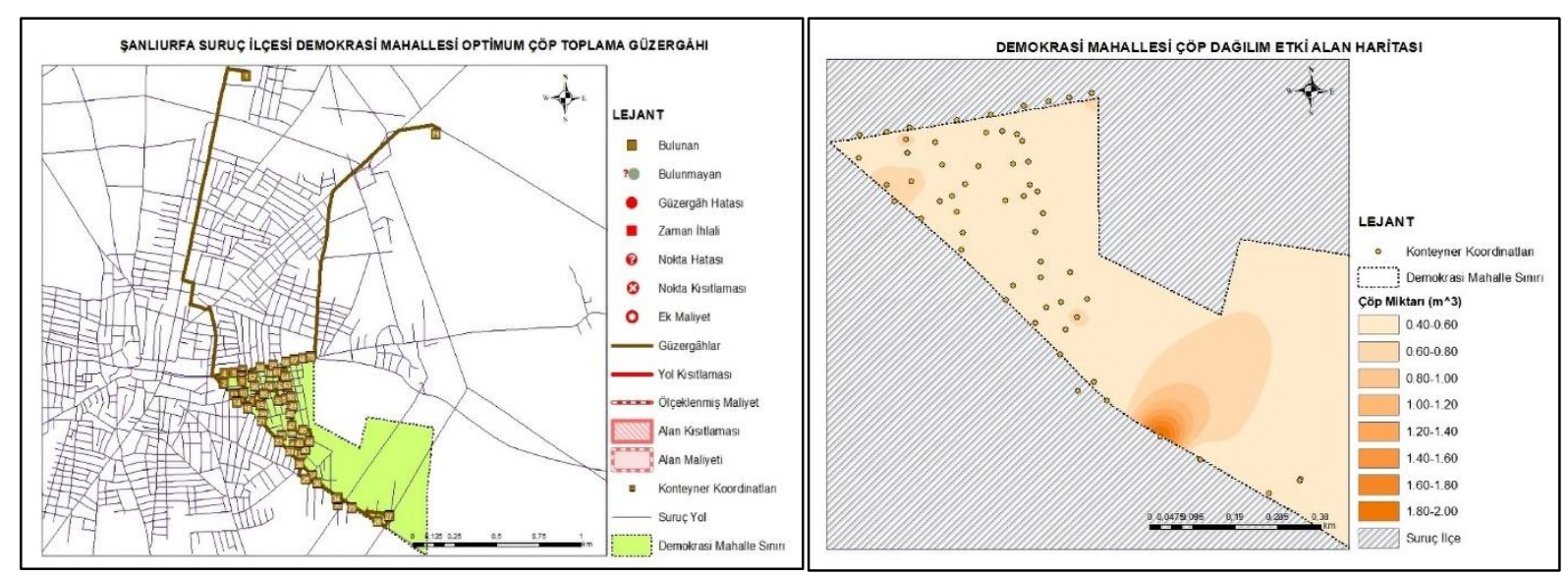

Şekil 6. Demokrasi Mahallesi optimum katı atık toplama güzergâhı ve alansal katı atık dağı̆ım haritası

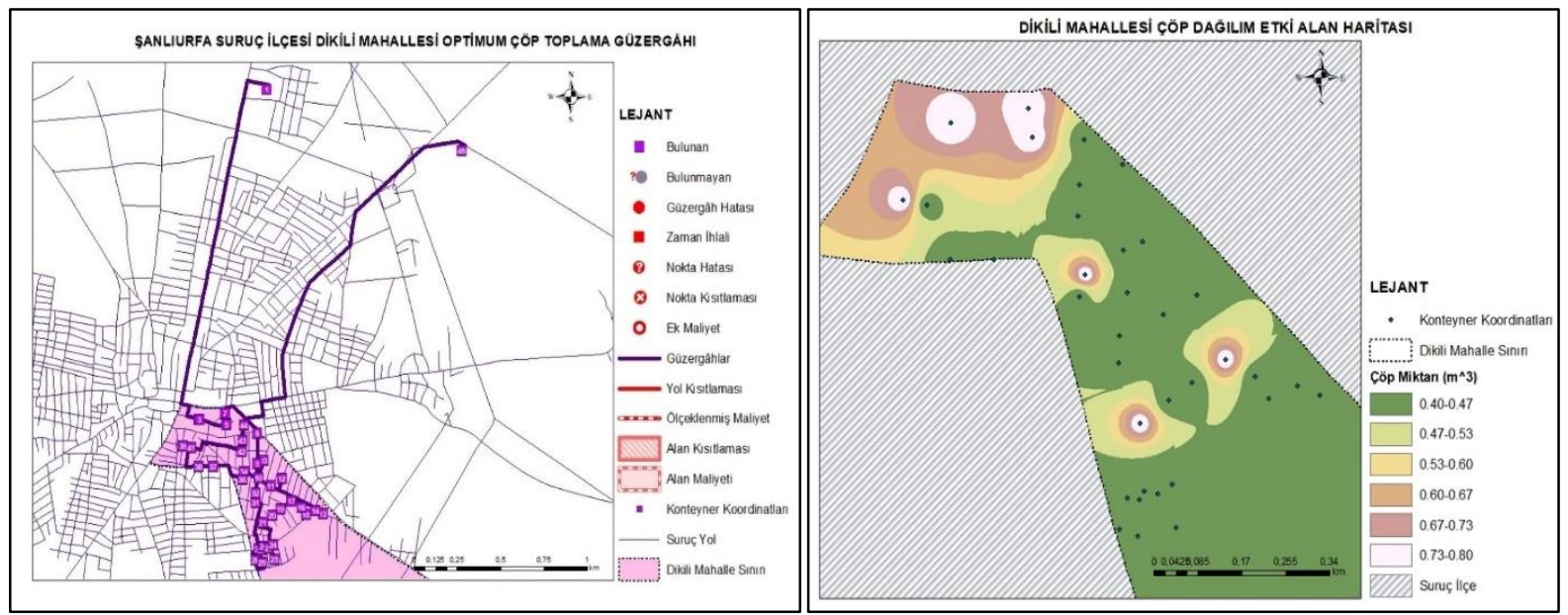

Şekil 7. Dikili Mahallesi optimum katı atık toplama güzergâhı ve alansal katı atık dağılım haritası

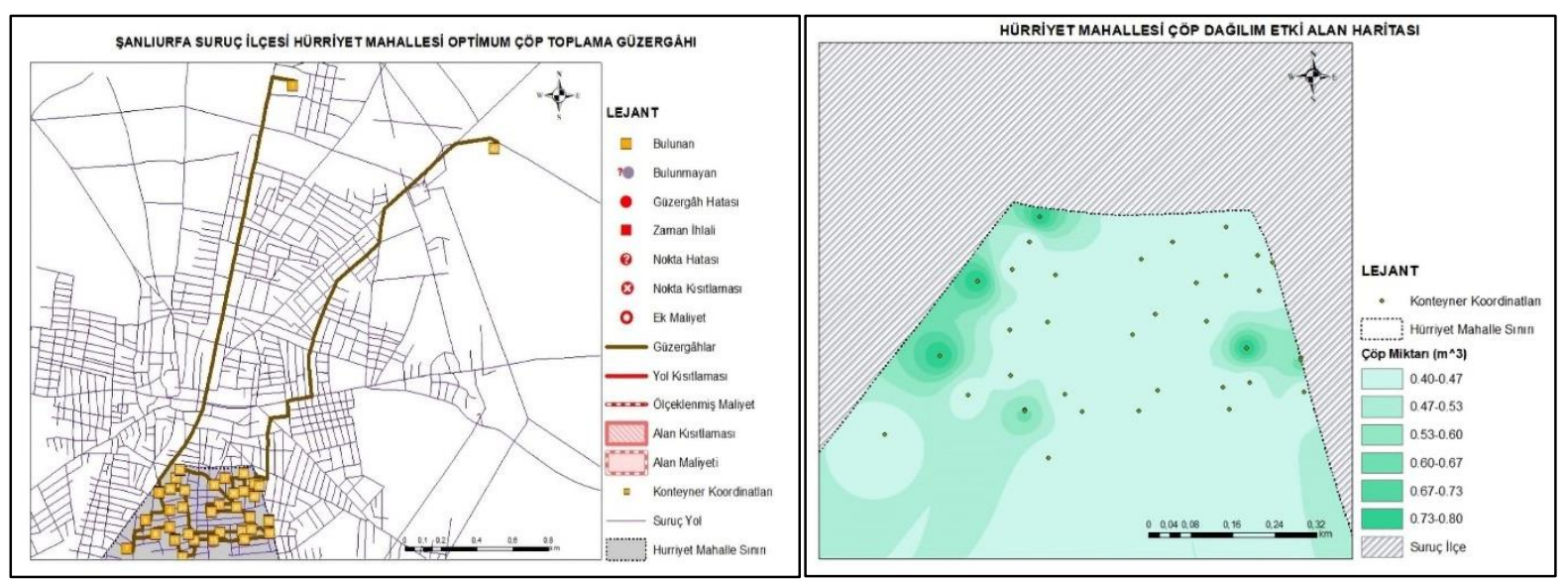

Şekil 8. Hürriyet Mahallesi optimum katı atık toplama güzergâhı ve alansal katı atık dağı̆ım haritası 

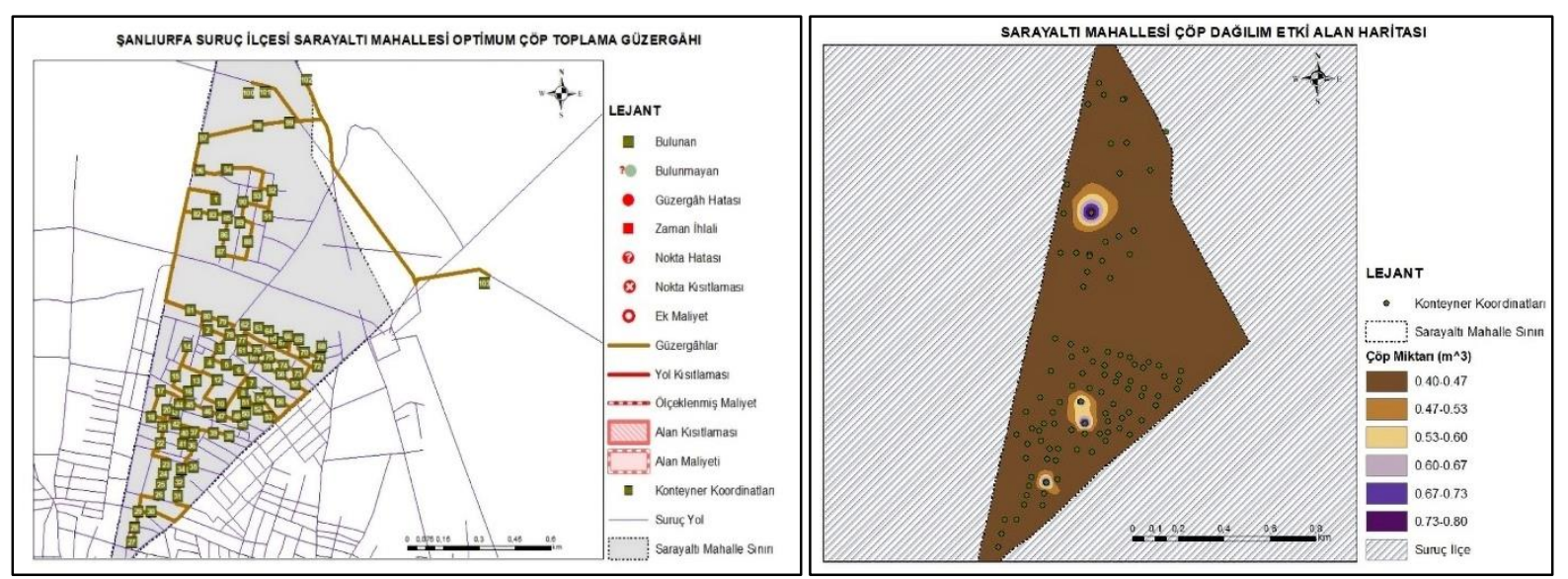

Şekil 9. Sarayaltı Mahallesi optimum katı atık toplama güzergâhı ve alansal katı atık dağılım haritası
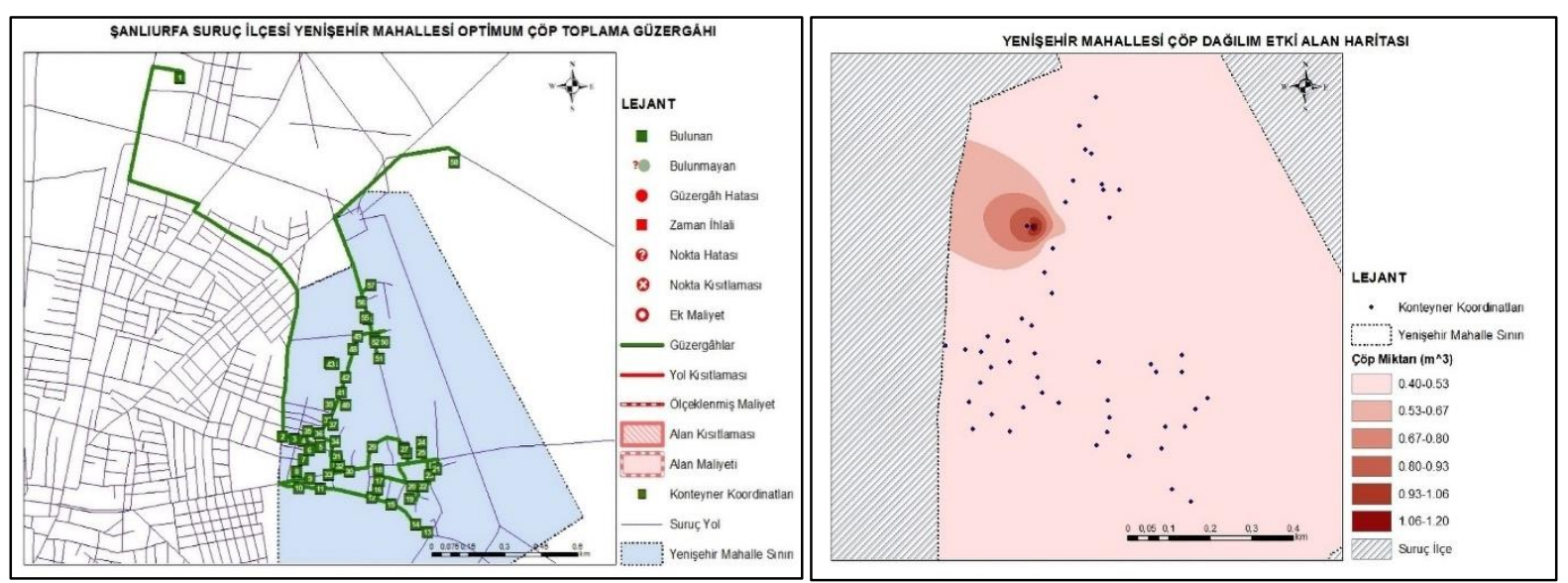

Şekil 10. Yenişehir Mahallesi optimum katı atık toplama güzergâhı ve alansal katı atık dağılım haritası
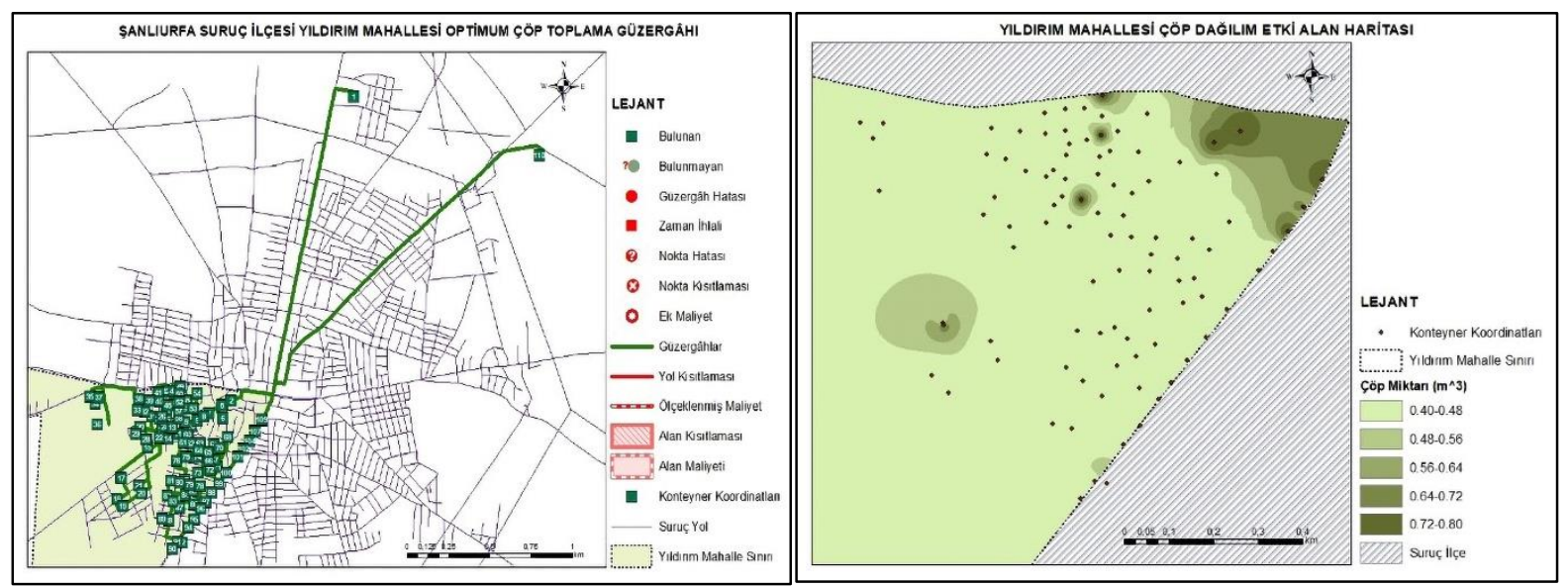

Şekil 11. Yıldırım Mahallesi optimum katı atık toplama güzergâhı ve alansal katı atık dağı̆ım haritası

\section{Sonuç ve Öneriler}

Bu çalışmada; CBS kullanılarak katı atık toplama, optimum güzergah (taşıma optimizasyonu) ve alansal katı atık dağılım haritaları hazırlanmıştır. Bu çerçevede güzergâh analiz optimizasyonu ve alansal katı atık dağılım haritaları için gerekli veriler belirlenmiştir. Her bir verinin hangi şekilde kullanılması gerektiği ve hangi analiz yönteminin seçilmesi gerektiği tespit edilmiştir. Mevcut toplama ve taşıma işlemi, genel olarak belirli bir güzergâha bağlı olmadan araç şoförlerinin inisiyatiflerinde belirlenen güzergâhlar kullanılarak gelişi güzel bir biçimde kat edilmektedir. Kat ettikleri yıllık toplam yol 52 
$177.5 \mathrm{~km}$ iken yapılan optimizasyon çalışması sonucu yıllık toplam yol $41084.6 \mathrm{~km}$ olarak hesaplanmıştır. Yaklaşık olarak \%27'lik yoldan kazanç sağlanmıştır. Optimizasyon çalışmaları sonucu elde edilen \%27'lik yıllık yol kazancı yaklaşık olarak 11092.9 km'lik bir yola denk gelmektedir. Günlük yol kazanc1 10 merkez mahalleye ortalama $30.39 \mathrm{~km}$ olarak düşmektedir. Buradan hareketle mahalle başına düşen günlük ortalama yol 3.04 km'ye denk gelmektedir. Özellikle fayda maliyet analizleri yapılarak bu sistemin düzgün çalışabilmesi, analizlerde kullanılan verilerin hassasiyetleri ile doğru orantılı olması ve verilerin oluşturulması sırasında gerekli hassasiyetlerin gösterilmesi, sonuçların doğruluğu açısından çok önemlidir. Alansal katı atık dağılım haritaları mahalleler arasındaki kirlilik kıyaslamasını bizlere verirken, aynı mahalle içindeki bölgesel kirlilik yükünü de göstermektedir. Böylece mevcut kirli bölgelere zaman kaybetmeden müdahale etme imkânına olanak vermektedir.

Sonuç olarak, belediyelerin katı atık toplama ve taşıma işlemlerinde; güzergâh belirleme işlemlerinde, alansal katı atık dağılım haritalarının hazırlanması işlemlerinde coğrafi bilgi sistemi altyapısına sahip teknolojilerinin kullanılması, ekonomik ve çevresel kazançlar açısından ciddi bir paya sahip olduğu görülmüştür. Tasarruf kapsamında yapılacak çalışmaların hayata geçirilmesi ile birlikte elde edilecek toplam fayda, direkt olarak ülke kaynaklarına büyük katkı sağlayacaktır.

Analizler, seçilen bölgeye ait gerçek veriler yardımı ile yapılmıştır. Güzergâh optimizasyonu ve alansal katı atık dağılım haritaları ile özellikle yerel yönetimlerde karar vericilerin çözüme daha kolay ve hızlı ulaşılabileceği düşünülmektedir. Araçların yaklaşık 1/3 oranında daha az kullanılmalarından dolayı ortaya çıkan amortisman, bakım ve onarım, yedek parça ve işçilik maliyetleri gibi kullanıma bağlı masraflardaki düşüş dikkate alındığında buradan elde edilecek tasarrufun da giderek artacağı düşünülmektedir. Elde edilen bu haritalardaki noktalar ve güzergahlar katı atık toplama ve taşımanın yanı sıra, sokak ve cadde temizliğinde çalışan işçiler içinde dikkate almaları gereken iyi bir rehber niteliğindedir. Belirli mıntıkalara göre temizlik işlemlerini yapan temizlik işçilerinin denetlenmesini sağlayan işçi çavuşlarının da denetleme - kontrol işlemlerini daha seri yapacağ 1 ve bu sayede denetleme araçlarında yakıttan tasarruf sağlanırken, kısa zamanda çok daha fazla alana ait denetimin gerçekleştirilmiş olacağı düşünülmektedir.

\section{Teşekkür}

Bu çalışma 17202 proje numarası ile Harran Üniversitesi Bilimsel Araştırma Projeleri Koordinasyon (HÜBAK) Birimi tarafindan desteklenmiştir.

\section{Kaynaklar}

[1] Ziadat A.H., Mott H. 2005. Assessing Solid Waste Recycling Opportunities for Closed Campuses. Management of Environmental Quality an International Journal, 16: 250-256.

[2] Frosch R.A. 1996. Toward the end of Waste: Reflections on a New Ecology for Industry. Technology Trajectory and The Human Environment. National Academy Press, 125:157-167.

[3] Alpaslan M.N. 2005. Katı Atıkların Yönetimi. TMMOB Çevre Mühendisleri Odası Yayınları, 1012 Şubat, 268-300.

[4] Yaydırgan T. 2018. Mahalli İdareler için Evsel Katı Atık Tarife Belirleme Yöntemi. Yüksek Lisans Tezi, Namık Kemal Üniversitesi, Fen Bilimleri Enstitüsü. 131s.

[5] Öztürk M. 2013. Çöp Toplama Maliyeti Nasıl Düşürülebilir? İller ve Belediyeler Dergisi, 777 778: 55-62.

[6] AYY (Atık Yönetimi Yönetmeliği). 2015. Yayımlandığı Resmi Gazete Sayı: 29314 ve Tarih: 02.04.2015.

[7] Töreyen G., Özdemir İ., Kurt T. 2011. ArcGIS 10 Desktop Uygulama Dökümanı. Sinan Ofset, Ankara, 200s.

[8] Yomralığlu T. 2000. Coğrafi bilgi sistemleri: Temel kavramlar ve uygulamalar. Güven Kitap Yayınları, İstanbul, 224s.

[9] Arslanoğlu M., Özçelik M. 2005. Sayısal Arazi Yükseklik Verilerinin İyileştirilmesi, TMMOB Harita ve Kadastro Mühendisleri Odası 10. Türkiye Harita Bilimsel ve Teknik Kurultayı, 28 Mart - 1 Nisan, Ankara. 
[10] Çener C., Çener E., Davraz A., Karagüzel R., Bulut C. 2010. Preliminary Findings In Egirdir Lake Water Quality: Assessment of In-Situ Measurements. Suleyman Demirel University Journal of Natural and Applied Sciences, I4-J: 72-83.

[11] Taylan E.D., Damçayırı D. 2016. Isparta Bölgesi Yağış Değerlerinin IDW ve Kriging Enterpolasyon Yöntemleri ile Tahmini. İMO Teknik Dergisi, 7551-7559.

[12] Anonim. 2018. http://www.tuik.gov.tr/PreIstatistikTablo.do?istab_id=2305 (Erişim Tarihi: 02.04.2018) 